\title{
Research on arbuscular mycorrhizae in Cuba: a historical review and future perspectives
}

\section{Furrazola $\mathrm{E}^{1 \dagger}$, Torres-Arias $\mathrm{Y}^{\mathbf{1}}$, Ojeda-Quintana $\mathrm{L}^{2}$, Fors $\mathrm{RO}^{3}$, Rodríguez- Rodríguez $\mathrm{R}^{4}$, Ley-Rivas $\mathrm{JF}^{1}$, Mena $\mathrm{A}^{4}$, González-González $\mathrm{S}^{5}$, Berbara $\mathrm{RLL}^{3}$, Queiroz MB $^{6}$, Hamel $\mathrm{C}^{7}$ and Goto BT ${ }^{6}$}

\author{
${ }^{1}$ Instituto de Ecología y Sistemática, CITMA Carretera Varona 11835 el Oriente y Lindero, La Havana 19, Calabazar, \\ Boyeros, La Havana, Cuba \\ ${ }^{2}$ CUM Cumanayagua, Universidad de Cienfuegos “Carlos R. Rodríguez”, Cienfuegos, Cuba \\ ${ }^{3}$ Universidade Federal Rural do Rio de Janeiro, Instituto de Agronomia, Seropedica, RJ, Brazil \\ ${ }^{4}$ Instituto Nacional de Ciencias Agropecuarias (INCA), Gaveta Postal 1, San José de las Lajas, Mayabeque, Cuba \\ ${ }^{5}$ Universidad de Temuco, Chile \\ ${ }^{6}$ Programa de Pós-graduação em Sistemática e Evolução, CB, Universidade Federal do Rio Grande do Norte, Campus \\ Universitário, 59072-970, Natal, RN, Brazil \\ ${ }^{7}$ Quebec Research and Development Centre, Agriculture and Agri-Food Canada, 2560 Hochelaga Blvd, Quebec City, \\ QC, Canada G1V $2 \mathrm{~J} 3$ \\ $\dagger$ In memorian
}

Furrazola E, Torres-Arias Y, Ojeda-Quintana L, Fors RO, Rodríguez-Rodríguez R, Ley-Rivas JF, Mena A, González-González S, Berbara RLL, Queiroz MB, Hamel C, Goto BT 2021 - Research on arbuscular mycorrhizae in Cuba: a historical review and future perspectives. Studies in Fungi 6(1), 240-262, Doi 10.5943/sif/6/1/16

\begin{abstract}
This review presents the development of researches on arbuscular mycorrhizae (AM) conducted in Cuba, a tropical Caribbean island rich in biodiversity. The key findings from this work are highlighted and presented as a stepping stone for future research. Cuban research has contributed to understand the diversity and functionality of AM in several tropical ecosystems, mainly evergreen forests, agroecosystems, sand dunes and pasturelands. Inventories were conducted in 10 out of 16 provinces reported 79 AM species, representing $25 \%$ of the known species worldwide. Cuban researchers have a great deal of expertise in Glomeromycota taxonomy and have described 11 new species, of which six were not reported elsewhere in the world. Furthermore, important studies conducted in Cuba have shed light on the mycotrophic plants, the role of AM in forest ecosystems, and their use in crop production. The contribution of AM to ecosystem processes is a priority line of research. Interdisciplinary and multidisciplinary researches are necessary to define the role of AM symbioses and improve biogeochemical models. Recently created Cuban Mycorrhizal Research Network will help to coordinate validation campaigns for various biofertilizers with training courses for Cuban farmers to disseminate the key results on AM. Despite the challenges for Cuban mycorrhizologists, molecular (genomic) techniques, stable isotopes and nuclear magnetic resonance should also be included as priority lines of research in the future.
\end{abstract}

Keywords - Arbuscular mycorrhizal fungi - diversity - ecosystems - mycorrhizal research symbiotic associations 


\section{Introduction}

Arbuscular mycorrhizal fungi (AMF, Glomeromycota) (Wijayawardene et al. 2020) are natural symbionts of a broad range of terrestrial plants (Smith \& Read 2008). The origin of these fungi dates from the Early Devonian, 400 million years ago, when they likely played a fundamental role in colonization of the land by plants (Strullu-Derrien \& Strullu 2007, Walker et al. 2021).

Plants in natural ecosystems depend mostly on mycorrhizae for the acquisition of nutrients in amounts adequate to sustain regular growth and reproduction (Khade \& Rodrigues 2009). They also provide several ecosystem services, such improvement of soil structure (Caravaca et al. 2006, Rillig \& Mummey 2006), suppression of weed populations (Rinaudo et al. 2010), and cycling of major elements such as carbon, phosphorus and nitrogen (Fitter et al. 2011).

Until the end of the 20th century, the taxonomy of AMF was based mainly on spore morphology, type of spore formation (acaulosporoid, entrophosporoid, gigasporoid, glomoid, and scutellosporoid) and wall structure (Gerdemann \& Trappe 1974, Walker \& Sanders 1986, Morton \& Benny 1990, Schenck \& Pérez 1990). However, many AMF species sporulate seasonally or not at all in the field (Gemma \& Koske 1988, Gemma et al. 1989, Błaszkowski et al. 2021) and minimum levels of root colonization are required to induce sporulation, which is regulated by the fungal genotype alone or in combination with host factors (Franke \& Morton 1994, Stutz \& Morton 1996). These factors can underestimate AMF diversity and limit the understanding of the role of those fungi in ecosystems (Lee et al. 2013). In the last two decades molecular approaches used to identify AMF species from cultures and field samples have been deep progress (Morton \& Redecker 2001, Kowalchuk et al. 2002, Rosendahl \& Stukenbrock 2004, Mummey \& Rillig 2007). Those techniques have been important in the description of new families, genera and species with improvement of phylogenetic relationships (Błaszkowski et al. 2017, 2021). They have also revolutionized ecology studies in AMF communities (Chagnon \& Bainard 2015) using new sequencing techniques to identify OTU in different field conditions.

Cuba possesses the highest richness of plants of all the Caribbean islands (CITMA 2014), it is one of the four islands with the highest number of plant species worldwide and it also has the largest number of plant taxa per $\mathrm{km}^{2}$. In 2010, 5778 native taxa of higher plants were reported in Cuba, of which 51.4\% were classified as endemics (Acevedo-Rodríguez \& Strong 2010, GonzálezTorres et al. 2016). The Cuban flora reaches 7500 taxa with Magnoliophyta, Pinophyta, Pteridophyta and Bryophyta included (González-Torres et al. 2013). This richness of ecosystems, plant diversity and the high number of new species described (Ferrer \& Herrera 1980, Furrazola et al. 2011b, Torres-Arias et al. 2017b) and probable new species found (Furrazola et al. 2019, TorresArias et al. 2019, Furrazola et al. 2020b) suggests that Cuba is an under-explored AMF hotspot in Central America.

A simple method for the evaluation of arbuscular mycorrhizal colonization (Herrera \& Ferrer 1977) has been described by researchers at the Institute of Botany of the Cuban Academy of Sciences (now the Institute of Ecology and Systematics - IES). Cuban researchers also studied plant response to inoculation (Rivera et al. 2003, Calderón \& González 2007, Mujica \& Batlle 2013, Ojeda et al. 2014, 2015, Martin \& Rivera 2015) and the function of mycorrhizal fungi in different ecosystems (Herrera et al. 1990, 1997, Herrera-Peraza \& Furrazola 2002, Furrazola et al. 2015), developing methods, in particular for recovering AM spores, from soil samples and for estimating extraradical mycelium biomass in soil (Herrera et al. 1984a, b, Becerra et al. 2002, Herrera-Peraza et al. 2004).

The research development in tropical countries as such in central America is incipient with highlight a few research groups. Historical reviews can be responsible to rescue preeminent researchers and research neglected by geopolitical barriers that hinder the dissemination of qualified information produced in isolated countries as such Cuba. Historical barriers despite political advances resulting from changes in government (Torres 2016) still remain as impediments to the dissemination of quality information.

Thus, this article traces (i) the historical development of research on arbuscular mycorrhizae in Cuba, (ii) identify the most important research areas developed and (iii) suggest strengthen areas 
to the future. This work is the legacy of a small community of committed researchers who are highly motivated to untangle the intricate clumps formed by these special soil fungi.

\section{Historical synthesis}

Research on AMF in Cuba began at the end of the 1970's when Dr. Ricardo Herrera conducted preliminary studies of the Cuban savannas (Borhidi \& Herrera 1977). He and Roberto L. Ferrer Sánchez also published a method for determining root colonization density by AMF (Herrera \& Ferrer 1977), thereby launching an era of research in Cuba. Other pioneering researchers was Nilades Bouza who studied the use of AM in growth of citrus (Bouza et al. 1986) and Maria Ofelia Orozco-Manso who studied AM in decomposing tree trunks (Orozco et al. 1986).

Research on the topic increased markedly in the 1990s, with essential help from the International Foundation for Sciences (IFS; Stockholm, Sweden). A classic work by Ferrer \& Herrera (1980) made an important contribution to the study of the genus Gigaspora in Cuba and began the extensive studies of AMF richness in evergreen forests at Sierra del Rosario, a UNESCO Biosphere Reserve (Ferrer \& Herrera 1988, Herrera et al. 1988a, b, 1990).

In 1970 the National Institute of Agricultural Sciences (INCA) of the Superior Education Ministry of Cuba was created. In the mid-1980s a Soil Microbiology group lead by Dr. Ana Velazco was formed in the Plant Nutrition Department (now known as the Plant Nutrition and Biofertilizers Department). Dr. Velazco participated in the Fifth International Course on Symbiotic Nitrogen Fixation held in 1988 at INRA in Montpelier, France, with great success and, almost simultaneously with Dr. Johana Döbereiner, she was able to isolate the bacteria Gluconoacetobacter diazotrophicus from AMF spores (Velazco et al. 1993). In 1987 Dr. Félix Fernández Martin created another group devoted to arbuscular mycorrhizae research.

Cuban researchers participated in the scientific meeting "Course on Research Techniques in Mycorrhizas" in 1985 supported by the IFS and CATIE (Centro Agrícola Tropical de Investigación y Enseñanza) in Costa Rica (Bouza et al. 1986, Ferrer et al. 1986, Herrera et al. 1986a, b, Orozco et al. 1986). This meeting was fertile ground, spurring the creation of the Latin-American Society of Mycorrhizae (SOLAM). The founding President of the Society was Dr. Ricardo Herrera, who was initially elected for two years, then later re-elected in 1990 until the society disbanded in December 2003.

The results of AMF research in Cuba are essentially found in conference proceedings, book chapters, theses and dissertations. These scientific events were organized until 1998 by the IES, when logistic problems and other difficulties prevented to celebrate these meetings during the next years. However, other Cuban institutions organize its own events where some works related with the theme mycorrhiza were debated.

Since 1985, the IES has organized the Botany Symposium. In 1990, that event coincided with the 1st Latin-American Symposium on Mycorrhiza, which took place in Havana and attracted a record number of participants for a meeting in Cuba, with 63 participants from Argentina, Brazil, Canada, Chile, Colombia, Costa Rica, France, Germany, Great Britain, Hungary, Mexico, Peru, Spain, United States, Venezuela and Cuba. That symposium was the start point for a series of meetings which have marked the initial phase of mycorrhizology in Cuba.

A major contribution of the IES mycorrhizologists appears in the book Fungi of the Caribbean (2001), published as part of the United Kingdom's Darwin Initiative. Inventories of different groups of fungi, including AMF, were conducted in three Cuban Biosphere Reserves: Sierra del Rosario, Ciénaga de Zapata and Cuchillas del Toa. That work led to the checklist of Caribbean fungi and a national strategy for fungi conservation in Cuba.

Studies on AMF carried out in Cuba or with the participation of Cuban researchers are increasingly being published in highly respected international scientific journals or books (HerreraPeraza et al. 2001, 2011, Herrera-Peraza \& Furrazola 2002, de la Providencia et al. 2004, 2007, Alonso et al. 2008, Cuenca \& Herrera-Peraza 2008, Furrazola et al. 2010, 2011b, 2015, 2016a, Rodríguez et al. 2011, Rodríguez-Rodríguez et al. 2013, Bainard et al. 2014, Błaszkowski et al. 2015a, de Andrade et al. 2017, Torres-Arias et al. 2017a, b). The practical experience with 
production, use of AMF inoculants in crop production, ecological and physiological studies Rivera et al. (2003) and Sánchez \& Furrazola (2018) stablished AM symbiosis management in the Caribbean in addition ecotechnologies using mycorrhizas and seeds treatments, respectively.

Most of the research centres for which AMF is an objective of study are located within or near the city of Havana, political and economical city of the island. However, several research groups have appeared in other parts of the country (Table 1).

Table 1 Principal Cuban institutions that have conducted research on arbuscular mycorrhizal fungi

\begin{tabular}{|l|l|}
\hline \multicolumn{1}{|c|}{ Institutions } & \multicolumn{1}{c|}{ Province } \\
\hline Instituto de Ecología y Sistemática (IES), Mycorrhizas Group & Havana \\
\hline $\begin{array}{l}\text { Instituto Nacional de Ciencias Agrícolas (INCA), Department of } \\
\text { Biofertilizers and Plant Nutrition }\end{array}$ & Mayabeque \\
\hline Universidad de La Habana (UH), Biology Faculty & Havana \\
\hline Universidad Agraria de La Habana (UAH) & Mayabeque \\
\hline Instituto Nacional de Investigaciones en Sanidad Vegetal (INISAV) & Havana \\
\hline Centro Nacional de Sanidad Agropecuaria (CENSA) & Mayabeque \\
\hline Instituto de Investigaciones Hortícolas Liliana Dimitrova (IIHLD) & Havana \\
\hline Centro Universitario Municipal (CUM) Cumanayagua & Cienfuegos \\
\hline Universidad de Cienfuegos Carlos R. Rodríguez & Cienfuegos \\
\hline Estación Experimental de Suelos y Fertilizantes Escambray (Barajagua) & Cienfuegos \\
\hline Instituto de Investigaciones de Viandas Tropicales (INIVIT) & Villa Clara \\
\hline Estación Experimental de Café de Jibacoa & Villa Clara \\
\hline Universidad de Ciego de Ávila (Facultad de Agronomía) & Ciego de Avila \\
\hline Universidad de Granma & Granma \\
\hline Universidad de Holguín & Holguín \\
\hline Universidad de Las Tunas & Las Tunas \\
\hline Centro Universitario de Guantánamo, Facultad Agroforestal & Guantánamo \\
\hline
\end{tabular}

\section{Fields of investigation}

The principal research lines involving AMF in Cuba are inoculum production and biotechnological applications, taxonomy and diversity, functions of the symbiosis in natural and agricultural ecosystems and mycorrhizal status of plant species.

\section{AMF production and application in Cuban agriculture}

In the early 1990s, the purchase of chemical fertilizers declined drastically as a result of reduced collaboration between Cuba and the countries of Eastern Europe. To mitigate the impact of fertilizer shortage, Cuba created the Biological-Agricultural Front with a mandate of developing biotechnologies for crop production (Herrera-Peraza et al. 2011). The IES led that Front related with the application of AMF in the country, in which approximately 22 Cuban institutions and 90 scientists and technicians participated. An important research effort between 1990 and 1993 led to the development of inoculation technologies and commercial AMF inocula, MicoFert ${ }^{\circ}$, produced by the IES.

MicoFert ${ }^{\circledR}$ was tested on several soils and crops, generating two datasets from 130 different experiments assessing the outcome of 548 replicated single inoculation trials (Herrera-Peraza et al. 2011). The datasets were from (i) high input agriculture (HIA; 343 replicated trials) or (ii) coffee plantations (CP; 205 replicated trials). Surprisingly, there was no significant relationship between plant response to AMF strains and soil test results in HIA systems. The researchers realized that soil fertility tests might not describe the soil conditions driving the distribution of AMF, and soil type might be a better indicator than soil test results. Selecting AMF strains according to soil properties is the key to effective use of AM inoculants in plant production. Several other experiments testing the influence of host plant, substrate, and additives have also advanced our understanding of the effect of AMF on plant growth (Ley-Rivas et al. 2009, 2015, 2017). 
The INCA has developed the commercial biofertilizers EcoMic ${ }^{\circledR}$ (solid substrate) and LicoMic ${ }^{\circledR}$ (liquid substrate) to be used on agroecological ecosystems. Positive synergisms and antagonisms among the biological components of the products were used to promote soil fertility, productivity, crop protection, and social equity (Rivera et al. 2003). INCA developed AMF commercial inocula (in vitro) to mycorrhization (Fernández-Suárez et al. 2017), detection of endosporic microorganisms (Alonso et al. 2008), induction of defense response in plantmicroorganism interactions (de la Noval \& Pérez 2004), and mycorrhizal influence on green manure crops (Martin \& Rivera 2015). Research on crop inoculation led to a reduction of inocula application dosages from 2-6 tha ${ }^{-1}$ to less than 1 tha $^{-1}$. A formulation for seed coating was an important improvement facilitating use of the inoculant by farmers. The host plants Brachiaria decumbens Steud. and Sorghum vulgare (L.) Pers. also improved the efficiency of AMF propagule production (Ferrer et al. 2004).

The EcoMic $®$ was evaluated in several field trials. The value of the product was demonstrated for rice, cotton, corn, wheat, soybean, beans, and sunflower crops produced in highand low-input agricultural systems (Rivera et al. 2003). Yield increases up to $43 \%$ were obtained with AMF inoculants. The numerous studies conducted by INCA confirmed that highly effective AMF strains are well adapted to a wide range of crops (Rivera et al. 2003, 2007), which enables successful inoculation of crops based simply on soil type.

\section{Taxonomy and diversity of AMF in Cuba}

An exhaustive recompilation, undertaken for this review, indicated that AMF richness in Cuba has been studied in ecosystems located in 10 of the 16 provinces. Sampled areas include forests, savannas, wetlands and sand dunes, as well as replacement ecosystems (forest plantations and grasslands) and agroecosystems, encompassing several soil and vegetation types.

In a recent review of the AMF in the Neotropics (Stürmer \& Kemmelmeier 2021), Cuba was reported as a high species richness between Caribbean islands. However, only 39 AMF species in Cuba were recorded. In this review we record 79 AMF species (Appendix 1), representing around $25 \%$ of global AMF diversity. A chronology of the appearance of these species is shown in Table 2.

Table 2 Arbuscular mycorrhizal fungal species reported in Cuba in chronological order

\begin{tabular}{|c|c|c|c|}
\hline Site/Province & AMF species & Habitat & Reference \\
\hline $\begin{array}{l}\text { Pinar del Río, Isla de la } \\
\text { Juventud, La Havana, Villa } \\
\text { Clara }\end{array}$ & $\begin{array}{l}\text { Cetraspora gilmorei, } \\
\text { Fuscutata heterogama, } \\
\text { F. savannicola, Gigaspora } \\
\text { margarita, Racocetra } \\
\text { alborosea, } R \text {. minuta, } \\
\text { Scutellospora calospora and } \\
\text { S. tricalypta }\end{array}$ & $\begin{array}{l}\text { Savanna, pastureland, } \\
\text { savannas on cuarcitic } \\
\text { sands, tobacco fields, } \\
\text { serpentinitic soils }\end{array}$ & $\begin{array}{l}\text { Ferrer \& } \\
\text { Herrera (1980) }\end{array}$ \\
\hline $\begin{array}{l}\text { Sierra del Rosario/ } \\
\text { Artemisa }\end{array}$ & $\begin{array}{l}\text { Acaulospora foveata, } \\
\text { A. laevis, A. scrobiculata, } \\
\text { A. spinosa, Funneliformis } \\
\text { monosporus, Glomus } \\
\text { clavisporum, } \\
\text { G. macrocarpum, } \\
\text { G. magnicaule, } \\
\text { G. microcarpum, } \\
\text { G. rubiforme, Rhizoglomus } \\
\text { fasciculatum, Sclerocystis } \\
\text { coremioides }\end{array}$ & Evergreen forests & $\begin{array}{l}\text { Ferrer \& } \\
\text { Herrera (1988) }\end{array}$ \\
\hline $\begin{array}{l}\text { Sierra del Rosario/ } \\
\text { Artemisa }\end{array}$ & $\begin{array}{l}\text { Acaulospora longula, } \\
\text { A. myriocarpa, A.rhemii, } \\
\text { Ambispora appendicula, }\end{array}$ & $\begin{array}{l}\text { Evergreen forests, } \\
\text { deciduous forest }\end{array}$ & $\begin{array}{l}\text { Herrera- } \\
\text { Figueroa et al. } \\
(2002)\end{array}$ \\
\hline
\end{tabular}


Table 2 Continued.

\begin{tabular}{|c|c|c|c|}
\hline Site/Province & AMF species & Habitat & Reference \\
\hline & $\begin{array}{l}\text { Archaeospora trappei, } \\
\text { Claroideoglomus etunicatum, } \\
\text { Dentiscutata scutata, } \\
\text { Diversispora spurca, } \\
\text { Entrophospora } \\
\text { infrequens, Funneliformis } \\
\text { geosporum, } \\
\text { F. mosseae, Glomus } \\
\text { aggregatum, } \\
\text { G. microaggregatum, } \\
\text { G. mortonii, G. pachycaule, } \\
\text { Halonatospora pansihalos, } \\
\text { Intraspora schenckii, } \\
\text { Paraglomus occultum, } \\
\text { Sclerocystis sinuosa, } \\
\text { Septoglomus constrictum }\end{array}$ & & \\
\hline $\begin{array}{l}\text { Sierra del Rosario/ } \\
\text { Artemisa }\end{array}$ & Kuklospora kentinensis & $\begin{array}{l}\text { Evergreen forests, } \\
\text { deciduous forest }\end{array}$ & $\begin{array}{l}\text { Orozco et al. } \\
(2003)\end{array}$ \\
\hline $\begin{array}{l}\text { Sierra del Rosario/ } \\
\text { Artemisa, Cuchillas del } \\
\text { Toa/Holguín }\end{array}$ & Glomus brohultii & $\begin{array}{l}\text { Evergreen forest, } \\
\text { Cuchillas del Toa, } \\
\text { Jaguani }\end{array}$ & $\begin{array}{l}\text { Herrera et al. } \\
(2003)\end{array}$ \\
\hline $\begin{array}{l}\text { Las Caobas, Gibara/ } \\
\text { Holguín }\end{array}$ & $\begin{array}{l}\text { Acaulospora koskei, } \\
\text { A. mellea, Claroideoglomus } \\
\text { claroideum, C. luteum, } \\
\text { Glomus albidum, } \\
\text { G. ambisporum, Rhizoglomus } \\
\text { clarum, Viscospora viscosa }\end{array}$ & Agroecosystem & $\begin{array}{l}\text { Medina et al. } \\
\text { (2010) }\end{array}$ \\
\hline Bainoa/Mayabeque & $\begin{array}{l}\text { Gigaspora albida, Glomus } \\
\text { glomerulatum }\end{array}$ & $\begin{array}{l}\text { Agroecosystem with } \\
\text { Glycime max }\end{array}$ & $\begin{array}{l}\text { Furrazola et al. } \\
\text { (2011a) }\end{array}$ \\
\hline Sierra del Rosario/Artemisa & Glomus crenatum & $\begin{array}{l}\text { Primary evergreen } \\
\text { forest }\end{array}$ & $\begin{array}{l}\text { Furrazola et al. } \\
\text { (2011b) }\end{array}$ \\
\hline $\begin{array}{l}\text { San Rafael pond, Las } \\
\text { Papas, San José de las } \\
\text { Lajas / Mayabeque }\end{array}$ & Glomus cubense & $\begin{array}{l}\text { Lagoon vegetation area } \\
\text { on a clay soil with } \\
\text { Cynodon nlemfuensis } \\
\text { and Mimosa pigra }\end{array}$ & $\begin{array}{l}\text { Rodríguez et al. } \\
\text { (2011) }\end{array}$ \\
\hline Bayamo/Granma & Acaulospora herrerae & $\begin{array}{l}\text { Agroecosystems, with } \\
\text { Panicum maximum, } \\
\text { Sporobolus indicus, } \\
\text { Byrsonima crassifolia }\end{array}$ & $\begin{array}{l}\text { Furrazola et al. } \\
(2013)\end{array}$ \\
\hline $\begin{array}{l}\text { Varadero, Hicacos } \\
\text { Peninsula/Matanzas }\end{array}$ & Claroideoglomus hanlinii & $\begin{array}{l}\text { Maritime dunes with } \\
\text { Phoenix dactylifera }\end{array}$ & $\begin{array}{l}\text { Błaszkowski et } \\
\text { al. (2015a) }\end{array}$ \\
\hline $\begin{array}{l}\text { Varadero, Hicacos } \\
\text { Peninsula/Matanzas }\end{array}$ & Diversispora varaderana & $\begin{array}{l}\text { Maritime sand dune } \\
\text { with Phoenix } \\
\text { dactylifera }\end{array}$ & $\begin{array}{l}\text { Błaszkowski et } \\
\text { al. (2015b) }\end{array}$ \\
\hline $\begin{array}{l}\text { Floristic Managed Reserve } \\
\text { San Ubaldo- } \\
\text { Sabanalamar/Pinar del Rio }\end{array}$ & $\begin{array}{l}\text { Acaulospora morrowiae, } \\
\text { Gigaspora decipiens, } \\
\text { Cetraspora aurigloba, } \\
\text { Septoglomus deserticola }\end{array}$ & $\begin{array}{l}\text { Semi-natural savannah, } \\
\text { recovering savannah } \\
\text { and an agroecosystem }\end{array}$ & $\begin{array}{l}\text { Furrazola et al. } \\
(2015)\end{array}$ \\
\hline $\begin{array}{l}\text { Pálpite, Ciénaga de } \\
\text { Zapata/Matanzas }\end{array}$ & $\begin{array}{l}\text { Acaulospora excavata, } \\
\text { A. tuberculata, } \\
\text { Claroideoglomus lamellosum, } \\
\text { Funneliformis halonatus }\end{array}$ & $\begin{array}{l}\text { Semideciduous forests } \\
\text { with Lysiloma } \\
\text { latisiliquum, Bucida } \\
\text { palustris, Bursera } \\
\text { simaruba }\end{array}$ & $\begin{array}{l}\text { Torres-Arias et } \\
\text { al. (2015) }\end{array}$ \\
\hline
\end{tabular}


Table 2 Continued.

\begin{tabular}{|c|c|c|c|}
\hline Site/Province & AMF species & Habitat & Reference \\
\hline $\begin{array}{l}\text { Santa Maria beach/ } \\
\text { La Havana }\end{array}$ & $\begin{array}{l}\text { Pacispora dominikii, } \\
\text { Rhizoglomus intraradices }\end{array}$ & Maritime sand dune & $\begin{array}{l}\text { González- } \\
\text { González et al. } \\
(2016) \\
\end{array}$ \\
\hline $\begin{array}{l}\text { San Andrés, Sierra de los } \\
\text { Órganos/Pinar del Rio }\end{array}$ & Glomus segmentatum & $\begin{array}{l}\text { Holm-oak wood forest } \\
\text { (Quercus cubana) } \\
\text { associated with Pinus } \\
\text { caribea }\end{array}$ & $\begin{array}{l}\text { Furrazola et al. } \\
\text { (2016a) }\end{array}$ \\
\hline $\begin{array}{l}\text { Livestock basin } \\
\text { "El Tablón," } \\
\text { Cumanayagua/Cienfuegos }\end{array}$ & $\begin{array}{l}\text { Cetraspora pellucida, } \\
\text { Dentiscutata heterogama, } \\
\text { Racocetra fulgida }\end{array}$ & $\begin{array}{l}\text { Pasturelands with } \\
\text { Megathyrsus maximus, } \\
\text { Pennisetum purpureum, } \\
\text { Brachiaria decumbens, } \\
\text { Cynodon nlemfuensis }\end{array}$ & $\begin{array}{l}\text { Furrazola et al. } \\
\text { (2016b) }\end{array}$ \\
\hline Sierra de Moa/Holguín & Sieverdingiatortuosa & $\begin{array}{l}\text { Pinewood (Pinus } \\
\text { cubensis Griseb., } \\
\text { Cirilla sp., Jacaranda } \\
\text { sp., Guetarda sp., } \\
\text { Metopium venosum } \\
\text { (Griseb.) Engler), } \\
\text { rehabilitated areas with } \\
\text { Casuarina equisetifolia } \\
\text { Fors and Anacardium } \\
\text { occidentale Lin. }\end{array}$ & $\begin{array}{l}\text { Torres-Arias et } \\
\text { al. (2017a) }\end{array}$ \\
\hline $\begin{array}{l}\text { Floristic Managed Reserve } \\
\text { San Ubaldo- } \\
\text { Sabanalamar/Pinar del Rio }\end{array}$ & Glomus herrerae & $\begin{array}{l}\text { Semi-natural savannah } \\
\text { (Scoparia dulcis L., } \\
\text { Cynodon dactylon (L.) } \\
\text { Pers., Sida brittonii } \\
\text { León, Portulaca pilosa } \\
\text { L., Tephrosia cinerea } \\
\text { L. Pers. and } \\
\text { Stylosanthes spp.) }\end{array}$ & $\begin{array}{l}\text { Torres-Arias et } \\
\text { al. }(2017 b)\end{array}$ \\
\hline $\begin{array}{l}\text { Pálpite, Ciénaga de } \\
\text { Zapata/Matanzas }\end{array}$ & Oehlia diaphana & $\begin{array}{l}\text { Agroecosystems with } \\
\text { Manihot } \\
\text { esculentaCrantz. } \\
\text { (cassava), Ipomoea } \\
\text { batatas (L.) Lam. } \\
\text { (sweetpotato) and Musa } \\
\text { paradisiaca L. (banana } \\
\text { plantain) }\end{array}$ & $\begin{array}{l}\text { Furrazola et al. } \\
\text { (2018) }\end{array}$ \\
\hline $\begin{array}{l}\text { Sierra del Rosario/ } \\
\text { Artemisa }\end{array}$ & Acaulospora denticulata & $\begin{array}{l}\text { Semi-natural } \\
\text { ecosystems }\end{array}$ & $\begin{array}{l}\text { Furrazola et al. } \\
(2019)\end{array}$ \\
\hline $\begin{array}{l}\text { Artemisa/La Havana/ } \\
\text { Mayabeque/Pinar del Rio }\end{array}$ & $\begin{array}{l}\text { Acaulospora elegans, } \\
\text { Diversispora eburnea, } \\
\text { D. trimurales, D. versiformis }\end{array}$ & $\begin{array}{l}\text { Agroecosystems with } \\
\text { Musa spp. }\end{array}$ & $\begin{array}{l}\text { Furrazola et al. } \\
(2020 \mathrm{a})\end{array}$ \\
\hline
\end{tabular}

The species reported in Cuba belong to 11 families and 25 genera (Fig. 1). Glomeraceae (37\%) and Acaulosporaceae (19\%) are the predominant families and the genera Glomus (18\%) and Acaulospora (18\%).

These groups are well represented in other latitudes and ecosystems (Zhao et al. 2003, PeñaVenegas et al. 2007, Tchabi et al. 2009, Cuenca \& Lovera 2010, Medina et al. 2010, Oehl et al. 2010, Stürmer \& Siqueira 2010) and have a high number of species. In spite of Glomus was the dominant genus with large number of names associated, there is not phylogenetic evidences 
supporting that assumption (Glomus as a rich genus) since only five species are recognized as belongs to this clade (Sieverding et al. 2014, Błaszkowski et al. 2019a, b, 2021).

The two best-explored regions for AMF diversity in Cuba correspond to natural forests. These are the Biosphere Reserve of Sierra del Rosario, Pinar del Rio province, in western Cuba, and Moa, Holguin province, in eastern Cuba. The latter and other studied wetland areas were confirmed as zones with the highest AMF species richness in the country (Herrera-Peraza et al. 2016, Torres-Arias et al. 2017a). Other ecosystems, including extensive agricultural systems and coastal sand dunes, have been found to harbour less diverse AMF communities (Furrazola et al. 2011a, González-González et al. 2016).

The species most commonly reported in Cuba, independent of the ecosystem, are Acaulospora scrobiculata, Diversispora spurca, Funneliformis mosseae, Glomus pachycaule, Rhizoglomus intraradices and Sclerocystis sinuosa. These could be considered generalist species adapted to different environments. The species restricted to certain ecosystems or regions are Acaulospora excavata, Gigaspora albida, Glomus herrerae, Glomus segmentatum, Racocetra minuta and Scutellospora tricalypta.

\section{A}

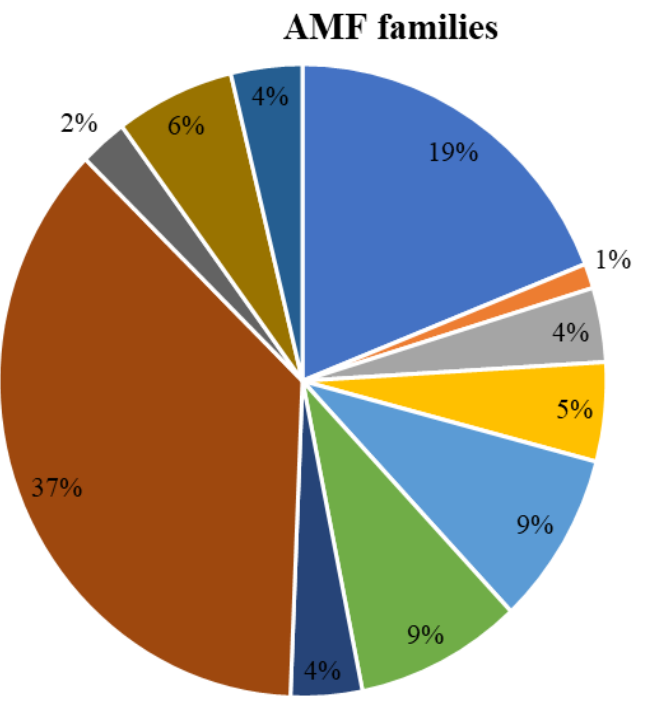

B

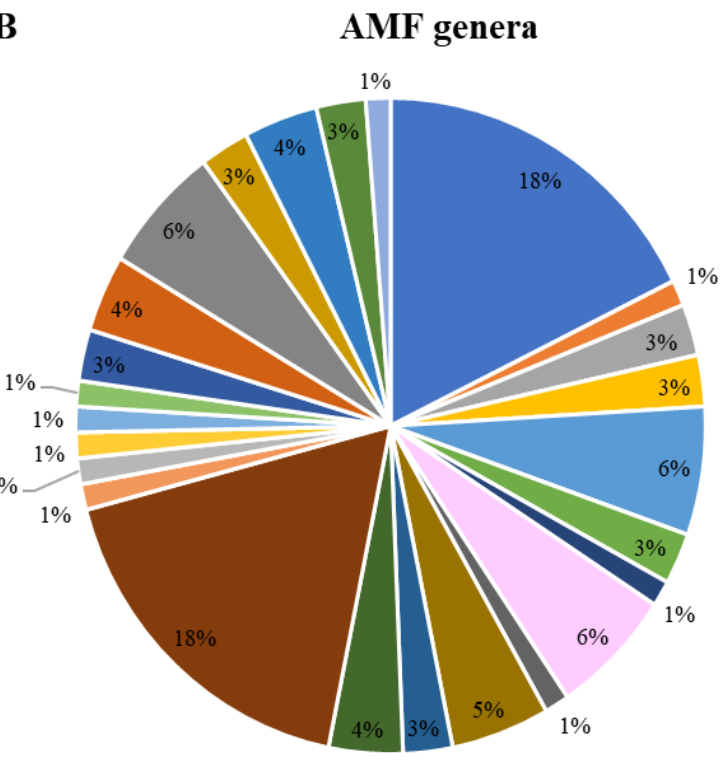

$$
\begin{aligned}
& \text { - Acaulosporaceae } \\
& \text { - Ambisporaceae } \\
& \text { - Archaeosporaceae } \\
& \text { - Dentiscutataceae } \\
& \text { - Diversisporaceae } \\
& \text { - Entrophosporaceae } \\
& \text { - Gigasporaceae } \\
& \text { - Glomeraceae } \\
& \text { - Paraglomeraceae } \\
& \text { - Racocetraceae } \\
& \text { - Scutellosporaceae } \\
& \text { - Acculospora } \\
& \text { - Ambispora } \\
& \text { - Archaeospora } \\
& \text { - Cetraspora } \\
& \text { - Claroideoglomus } \\
& \text { - Dentiscutata } \\
& \text { - Sieverdingia } \\
& \text { Diversispora } \\
& \text { - Entrophospora } \\
& \text { - Funneliformis } \\
& \text { - Fuscutata } \\
& \text { - Gigaspora } \\
& \text { - Glomus } \\
& \text { - Halonatospora } \\
& \text { - Intraspora } \\
& \text { - Kuklospora } \\
& \text { - Oehlia } \\
& \text { - Pacispora } \\
& \text { - Paraglomus } \\
& \text { - Racocetra } \\
& \text { - Rhizoglomus } \\
& \text { - Sclerocystis } \\
& \text { - Scutellospora } \\
& \text { - Septoglomus } \\
& \text { - Viscospora }
\end{aligned}
$$

Fig. 1 - Percentage of arbuscular mycorrhizal species distributed in families (A) and genera (B) reported in Cuba. 
The information on AMF taxonomy and diversity derived from Cuba is of special importance for three reasons. First, 11 of the approximately 330 species currently recognized in the Glomeromycota (Wijayawardene et al. 2020, Goto \& Jobim 2021) were described for the first time from Cuban specimens (Fuscutata savannicola, Racocetra alborosea, Racocetra minuta, Scutellospora tricalypta (Ferrer \& Herrera 1980), Glomus brohultii (Herrera et al. 2003), Glomus crenatum (Furrazola et al. 2011b), Glomus cubense (Rodríguez et al. 2011), Acaulospora herrerae (Furrazola et al. 2013), Claroideoglomus hanlinii (Błaszkowski et al. 2015a), Diversispora varaderana (Błaszkowski et al. 2015b), Glomus herrerae (Torres-Arias et al. 2017b)). Second, based on the results obtained to date, around $25 \%$ of the 55 species of Glomus (Wijayawardene et al. 2020) have been observed in Cuba. Third, an abundance of undescribed species have been found in Cuba. Between 30-40\% of the species found in surveys such as those conducted in Moa and Sierra del Rosario were previously undescribed (Torres-Arias et al. 2017a).

Although first described from Cuban ecosystems, some of these species have already been observed in other regions of the world, showing a broad distribution. Glomus brohultii and Fuscutata savannicola have been observed in diverse areas including natural, replacement and agricultural ecosystems. Reports of $G$. brohultii have come from Africa (Benin and Congo) and several South and Central American countries including Bolivia, Brazil, Colombia, Costa Rica, Peru and Venezuela (Herrera et al. 2003, Tchabi et al. 2009, Cuenca \& Lovera 2010). On the other hand, $F$. savannicola has been reported in agroecosystems of Benin (Tchabi et al. 2009) and more recently also in Ecuador. Other studies have indicated that Acaulospora herrerae occurs not only in eastern Cuba (Bayamo, Granma and Holguín provinces) in natural areas and agroecosystems, but also in northeastern Brazil (Furrazola et al. 2013, Torres-Arias et al. 2017a).

Other species described from Cuban keep endemic. Glomus cubense is present in natural and agricultural areas of western Cuba and has been used as part of AMF inoculants in various crops including tomato (Solanum lycopersicum L.), sweet potato (Ipomoea batatas (L.) Lam.), pasture (Panicum maximum Jacq.), corn (Zea mays L.), durum wheat (Triticum durum Desf.) and coffee (Coffea arabica L.) (Sánchez et al. 2000, Calderón \& González 2007, Terry \& Ruiz 2008, Fundora et al. 2009, Rodríguez et al. 2011). Racocetra alborosea has been reported in environments including grasslands within the province of Havana and white sand ecosystems in Guane, Pinar del Rio, as well as the wetlands of Ciénaga de Zapata, Matanzas (Ferrer \& Herrera 1980, Torres-Arias et al. 2017a, Furrazola et al. 2015).

Glomus crenatum has been reported in Sierra del Rosario, Moa and Ciénaga de Zapata (Furrazola et al. 2011b, Torres-Arias et al. 2015, 2017a). Meanwhile, Racocetra minuta and Scutellospora tricalypta have been reported exclusively in white sand ecosystems of Isla de la Juventud and grasslands of Macurije, Pinar del Rio (Ferrer \& Herrera 1980) and G. herrerae was described from an also a very particular ecosystem like white sand savannas on Managed Floristic Reserve San Ubaldo-Sabanalamar at Pinar del Río, province in western Cuba. In this reserve, the semi-natural savannah on quartzite sand is predominant, white sands originated from Holocene sandy deposits with secondary vegetal formations (Ricardo et al. 2009).

\section{Functions of the AM symbiosis in natural and agricultural ecosystems}

Several studies on the functioning of AM symbiosis in Cuba have been developed in evergreen forests of Sierra del Rosario. They have concentrated on functional characterization of the mycorrhizal symbiosis with primary forest trees, evaluating the influence of different soils on the mycotrophy and mycorrhizal dependency of seedlings (Ferrer \& Herrera 1988, Herrera et al. 1988a, b, 1990, 2004).

The results obtained indicated that mycorrhizal diversity and functioning follow two principal strategies. The first strategy, exuberant, occurs in ecosystems with high turnover and organic matter decomposition rates where available moisture is not a limiting factor (roadside slopes or forest gaps where heliophylous plants are prevalent). Exuberant AM associations promote plant growth and reproduction and therefore increase availability of photosynthetic carbon for the AMF. Consequently, low rootlets, external mycelia biomasses and high internal mycelium or endophyte 
density and biomasses are obtained. The result is a photosynthetically costly, but highly "aggressive" and efficient, mycorrhizal symbiosis. The second strategy, austerity, occurs in ecosystems with low turnover and decomposition rates (root mats are observed on the forest soil) and insufficient water availability. It is probably marked by lower photosynthetic rates (Herrera et al. 2004). These ecosystems are characterized by high rootlet and extraradical mycelial biomass and low internal mycelium density and biomass. The symbiosis is not photosynthetically costly and is typical of the final stage of tropical forests or climax stages.

The observations of Orozco et al. (2003) assessing the effect of natural sources of inocula from Sierra del Rosario support the assumption of exuberance and austerity as AMF lifestyles in different ecosystems. Growth stimulation was superior in plants inoculated with soil taken from a well-exposed roadside slope compared to primary forest soils. The effect obtained with the roadside slope AMF community would be equivalent to the effect of AMF communities originating from agricultural soils fully exposed to solar radiation, where avid photosynthate-consuming generalists predominate. A richer AMF community was found in the rooting soil of plants inoculated with the exuberant community of the well-exposed roadside slope than in plants inoculated with primary forest soil (36 vs 24 AMF morphospecies).

Low availability of moisture selects for austere AMF communities in Sierra del Rosario, as does reduced availability of photosynthates. Increases in water stress and the advancement of successional stages select for a biota able to survive in harsh conditions. The impact of low moisture availability on AMF diversity can be attributed to reduced turnover rates in dry forests (Herrera et al. 1997). According to these authors, moisture shortage leads to organic matter accumulation, which results in more niches that could be occupied by a higher number of subordinate AMF species.

In these evergreen forests, one of the two defined functional strategies is characterized by lower turnover rates (low organic matter decomposition), higher water stress related to more complicated nutrient conservation mechanisms (occurrence of root mats on), larger quantities of dead organic matter on soil and probably lower photosynthetic rates as consequence of lower leaf specific area (Herrera et al. 1997). This austerity condition (related with the $K$ end along the universal $r-K$ continuum) and predominant in primary forest of this Biosphere Reserve selects for richer AMF communities. The highest level of richness in Sierra del Rosario was found in a primary forest mainly composed of Pseudolmedia spuria Sw. Griseb., Oxandra lanceolata (Sw.) Baill., Trophis racemosa (L.) Urb., Matayba apetala (Macf.) RDLK., Dendropanax arboreus (L.) DEC. et Planch. and Calophyllum antillanum Britt. as woody species and 27 AMF species and/or morphospecies, followed by an old closed gap, with Zanthoxylum martinicense (Lam.) DC as principal plant species and 26 AMF species in a natural plot with predominance of Hibiscus elatus Sw. and 25 AMF species.

A study of Glomeromycotan communities associated with forest successional stages in Sierra del Rosario indicated a recurrent pattern in the species profile. There were one to three very dominant AMF morphospecies, about five dominant species, and several subordinate species (Halffter 1992).

Studies of the functioning of symbiosis and AMF communities have also been developed for eastern Cuba. The region of serpentine ultramafic rocks in the northeast of the eastern provinces has soils that support one of the highest floristic diversity and endemism levels on the island (Berazain 2003). Plant species in this region are adapted to oligotrophic conditions and toxicity from heavy metals, especially Ni, Cr and Co (Berazain 1981). Four groups of AMF species exist in these zones: (i) species adapted to natural pine groves ("pinares"); (ii) species adapted to calcium and magnesium rich forest; (iii) species striving in both environments, and (iv) species exclusively in planted forests. The AMF species observed in those forests are characterized by small spores (47 $\mu \mathrm{m}$ and $100 \mu \mathrm{m}$ ) and negative binomial distributions, which suggest the presence of ancestral AMF communities that are rich in local endemism, as such the plant communities in that region of Cuba (Herrera-Peraza et al. 2016)

Eleven glomeromycotan species were classified as indicators of ultramafic calcareous soils, pristine, contaminated by mining and rich in aluminum, nickel, cobalt, or copper, and natural (Herrera-Peraza et al. 2016). Most of these indicator species belong to the genus Glomus, 
supporting the conclusion that species belonging to the order Glomerales are more stress-tolerant than the Diversisporales (de Souza et al. 2005). Those species produced typical dark-pigmented brown glomerospores.

\section{Mycorrhizal status of plant species}

Several research programs on mycotrophy of plant species have been developed in Cuba. Herrera \& Ferrer (1980) carried out the pioneering work reporting 17 plant species as mycotrophic. Then, Ferrer \& Herrera (1985) analyzed 75 new plant species belonging to 37 families and showed only one (Polygonaceae) was not mycorrhizal. Amarantaceae, Annonaceae, Arecaceae, Asclepiadaceae, Bignoniaceae, Boraginaceae, Cactaceae, Caesalpinaceae, Clusiaceae, Commelinaceae, Compositae, Cyperaceae, Dilleniaceae, Eriocaulaceae, Euphorbiaceae, Fabaceae, Hypericaceae, Malpighiaceae, Malvaceae, Meliaceae, Mimosaceae, Moraceae, Myrtaceae, Poaceae, Proteaceae, Rhamnaceae, Rosaceae, Rubiaceae, Rutaceae, Sapindaceae, Sapotaceae, Scrophulariaceae, Solanaceae, Sterculiaceae, Tiliaceae and Verbenaceae were classified as mycotrophic families.

These authors also studied 60 plant species in an evergreen forest at the Biosphere Reserve of Sierra del Rosario (Ferrer \& Herrera 1988). This time, Araliaceae, Flacourtiaceae, Lauraceae, Melastomataceae, Menispermaceae, Myrsinaceae, Simarubaceae and Smilacaceae were added to the list of mycorrhizal plant families in Cuba. Other studies addressing the mycorrhizal status of plant species were performed by Cruz (1987) and Rodríguez-Rodríguez (2014). The latter evaluate 20 endemic plant species in white sand ecosystems within the Managed Floristic Reserve of San Ubaldo-Sabanalamar in the Pinar del Rio province. As a result, Asteraceae, Cistaceae, Ericaceae, Phyllanthaceae and Polygalaceae were added as mycotrophic plants (Rodríguez-Rodríguez et al. 2014), totalizing 50 families. Recently, Furrazola et al. (2020b) defined the arbuscular mycorrhizal status of an endemic and critically endangered plant species Coccothrinax crinita Griseb. \& H. Wendl. ex C. H. Wright, Becc., Arecaceae strictly to Bahía Honda municipality which is considered one of the most endangered palms in the insular territories of America (Jestrow et al. 2018).

\section{Status of AM biochemical and genetic research in Cuba}

Genetic research on AM has barely begun. Based on previous studies (Sanders et al. 1992, Perotto et al. 1994, Simon 1996), de la Providencia et al. (2002) developed a polyclonal antibody against Rhizoglomus clarum to enable its detection by indirect immunofluorescence (IF) and enzyme-linked immunosorbent assay (ELISA). The antibody raised allows detection of $R$. clarum spores and extraradical mycelium without crossed reactions with other species of Glomerales (de la Providencia 2002).

Furrazola et al. (2010) used the LSU nrRNA gene sequence and phylogenetic tools to describing Glomus candidum (now as Claroideoglomus candidum). Rodríguez et al. (2011) also used molecular markers when performing a phylogenetic analysis of the rDNA ITS region and $\mathrm{H}+\mathrm{ATPase}$ in their description of Glomus cubense. On the other hand, in the case of Acaulospora herrerae (Furrazola et al. 2013), partial sequences of the LSU rRNA gene confirm the new fungus whereas PCR reactions were performed according Goto et al. (2012) with some modifications.

Rodríguez et al. (2014) studied the spore morphologic characteristics and other molecular protocols like rDNA ITS region and V-H+-ATPasa, in spores of INCAM 2 strain, which was identified as Funneliformis mosseae.

Recently, Rodríguez-Yon et al. (2021) published a taxon-discriminating molecular marker with the purpose of trace and quantify the presence of a mycorrhizal inoculum in roots and soils of different agroecosystems. Normally is difficult to connect yield effects with any AMF strain abundance in roots due to the lack of an adequate methodology to trace this taxon in the field. In order to that, it is necessary to establish an accurate evaluation framework of its contribution to root colonization separated from native arbuscular mycorrhizal fungi. A taxon-discriminating primer set was designed for Glomus cubense isolate (INCAM-4, DAOM-241198) based on the ITS nrDNA 
marker and two molecular approaches were optimized and validated (endpoint PCR and quantitative real-time PCR) to trace and quantify G. cubense isolate in root and soil samples under greenhouse and environmental conditions. Different AMF taxa were used for endpoint PCR specificity assay, showing that primers specifically amplified the INCAM-4 isolate yielding a 370 bp-PCR product. In the greenhouse an assay with Urochloa brizantha plants inoculated with three isolates (Rhizoglomus irregularis, R. clarum, and G. cubense) and environmental root and soil samples were successfully traced and quantified by qPCR. This study demonstrates for the first time the feasibility to trace and quantify the G. cubense isolate using a taxon-discriminating ITS marker in roots and soils. The validated approaches reveal their potential to be used for the quality control of other mycorrhizal inoculants and their relative quantification in agroecosystems.

\section{Priority research lines for AMF studies in Cuba}

In the future, taxonomic identification of AMF should be based on both morphological criteria and molecular analysis as suggested by Błaszkowski et al. (2021). The high number of glomeromycotan fungi recently described around the world show the necessity an improve those methods to distinguish fungi with very similar morphology and absence of synapomorphies in the Glomeraceae (Błaszkowski et al. 2018, 2021, Corazon-Guivin et al. 2019, Jobim et al. 2019).

Despite the importance of mycorrhizae for the maintenance of biodiversity and ecosystem functions, surprisingly little information exists about landscape-scale biogeographical patterns of AM fungal species and the environmental factors that influence species distributions (Chaudhary et al. 2018). However, landscape-scale studies linking the distributions of mycorrhizal fungal species to environmental factors are essential to a full understanding of the importance of their role in ecosystem functioning and services provided across landscapes. Fortunately, the ecosystem approach in mycorrhizal research is being implemented in Cuba. A project titled "A Landscape Approach to the Conservation of Threatened Mountain Ecosystems" was financed by the United Nations Development Program (UNDP). The UNDP project "Reduction of vulnerability to coastal flooding through ecosystem-based adaptation in the south of Artemisa and Mayabeque provinces," involving the application of mycorrhizal inocula in forest nurseries to increase survival of seedlings during transplant to the field, was also approved. Those project looks at ways to reduce the vulnerability of coastal communities under climate change conditions, including coastal erosion, flooding, and saline intrusions, through reforestation of degraded coastal zones of mangroves and wetlands.

The role of AM symbiosis in ecosystem physiology is another subject that requires attention in different parts of the world. The study of AMF in protected areas or natural ecosystems should be a strong focus in Cuba. As noted by Turrini \& Giovannetti (2012), studying the occurrence and distribution of potentially endemic AMF ecotypes in protected areas worldwide provides a strategic perspective from which to increase awareness of the importance of these beneficial symbionts.

The functional diversity of AMF needs to be incorporated into our research. Angelard et al. (2010), working with genetically different AMF isolates of Rhizhoglomus intraradices, found functional differences among them, producing different effects in host plants. Each fungal species or strain may play a different role in biogeochemical cycles or plant success (Montaño et al. 2012). The principal Cuban AMF inoculants are MicoFert® (composed of several AMF species) and EcoMic ${ }^{\circ}$ (composed of a single AMF species).

The development of nickel mining in eastern Cuba makes it essential to carry out AMF inventories in undisturbed, transformed or endangered ecosystems, as well as to develop ecotechnologies involving AMF to rehabilitate these ecosystems. The IES has an incipient AMF collection of native and introduced AMF in vivo cultures, (Colección Cubana de Hongos Micorrizógenos Arbusculares - CCHMA) which provides inocula or fungi for national researchers. Cuban scientists have traditionally collaborated very productively with different fungal collections at over the world. These collaborations needs to be relaunched.

There are barriers that, if not lifted, may hamper the effectiveness of priority research in Cuba. Mycorrhizologists are an aging workforce in this country. A new challenge is the recruitment 
of highly qualified young technicians and researchers who can conduct effective research in Cuba. Government regulations are also needed to allow the introduction of foreign inocula for long-term evaluation and comparison with our commercial inocula. Finally, stable isotopes, nuclear magnetic resonance (NMR), and genetic techniques have become essential tools in AMF research, but accessing these tools still a very challenging for Cuban mycorrhizologists.

\section{Concluding remarks}

Since the first publication on mycorrhizae in Cuba in 1977 approximately four decades ago, Cuban research has been pursued intensely and successfully, making important advances in knowledge about AMF diversity and the functioning of ecosystems that are among the richest and most complex on earth, providing knowledge and effective biotechnologies to improve the efficiency and sustainability of agroecosystems. Given the broad diversity of vascular plants and ecosystems in Cuba, AMF diversity in the country could exceed the 79 species reported to date. Strains that are as yet unknown may be important in the future for greenhouse or field production, in landscape preservation combining economists and conservationists' perspectives, and in the production of commercial inocula.

The study of AMF species from natural and transformed ecosystems will provide a better way to employ the AM symbiosis under different edapho-climatic conditions. This will improve our understanding of what kind of AMF to apply in order to improve plant production under sustainable production systems. In addition, AMF might contribute to the rehabilitation of different ecosystems through their biofertilizer capacity. With a long way to go, new challenges will arise in the near future in those fields.

\section{Acknowledgments}

In memory to Eduardo Furrazola victim of COVID-19 during correction of this proof. He left leaving a broad legacy to mycorrhizology in Latin America. We sincerely thank Esther Collazo, Maritza Portierł , Osbel Gómez, Carlos Massia and Yosvany Gutiérrez for their technical assistance. They participated in various productions of MicoFert ${ }^{\circledR}$ over many years, as well as in field expeditions. Our work was supported by the following UNDP projects: "A Landscape Approach to the Conservation of Threatened Mountain Ecosystems" and "Reduction of Vulnerability to Coastal Flooding through Ecosystem-based Adaptation in the South of Artemisa and Mayabeque Provinces", as well as by Conselho Nacional de Desenvolvimento Científico e Tecnológico (CNPq) that provided research grants to BT Goto (proc. 311945/2019-8) and MB Queiroz.

\section{References}

Acevedo-Rodríguez P, Strong MT. 2010 - Catalogue of Seed Plants of the West Indies. Smithsonian Contributions to Botany 98, 1-1192.

Alonso LM, Kleiner D, Ortega E. 2008 - Spores of the mycorrhizal fungus Glomus mosseae host yeasts that solubilize phosphate and accumulate polyphosphates. Mycorrhiza 18, 197-204.

Angelard C, Colard A, Niculita-Hirzel H, Croll D, Sanders IR. 2010 - Segregation in a mycorrhizal fungus alters rice growth and symbiosis-specific gene transcription. Current Biology 20, 1216-1221.

Bainard LD, Dai M, Furrazola-Gómez E, Torres-Arias Y et al. 2014 - Arbuscular mycorrhizal fungal communities are influenced by agricultural land use and not soil type among the Chernozem great groups of the Canadian Prairies. Plant and Soil 387, 351-363.

Becerra AG, Soares ACF, Herrera-Peraza RA. 2002 - Comparación de dos métodos de extracción de esporas de hongos del orden Glomales (Zygomycetes). Periódico Biociências9 (2), 31-38.

Berazain R. 1981 - Reporte preliminar de plantas serpentinicolas acumuladoras e hiperacumuladoras de algunos elementos. Revista del Jardín Botánico Nacional Habana 2 (1), $48-59$. 
Berazain R. 2003 - Moa: Paraíso de los botánicos. Nota sobre su flora y vegetación. Resúmenes, IV Conferencia Internacional sobre Serpentinita, Jardín Botánico Nacional de Cuba, 70-80.

Błaszkowski J, Chwat G, Góralska A. 2015a - Acaulospora ignota and Claroideoglomus hanlinii, two new species of arbuscular mycorrhizal fungi (Glomeromycota) from Brazil and Cuba. Mycological Progress 14, 18.

Błaszkowski J, Furrazola E, Chwat G, Góralska A et al. 2015b - Three new species of arbuscular mycorrhizal fungi (Glomeromycota). Mycological Progress 14, 105.

Błaszkowski J, Kozłowska A, Crossay T, Symanczik S, Al-Yahya’e MN. 2017 - A new family, Pervetustaceae with a new genus, Pervetustus, and P. simplex sp. nov. (Paraglomerales), and a new genus, Innospora with I. majewskii comb. nov. (Paraglomeraceae) in the Glomeromycotina. Nova Hedwigia 105 (3-4), 397-410.

Błaszkowski J, Kozłowska A, Niezgoda P, Goto BT, Dalpé Y. 2018 - A new genus, Oehlia with Oehlia diaphana comb. nov. and an emended description of Rhizoglomus vesiculiferum comb. nov. in the Glomeromycotina. Nova Hedwigia 107(3-4), 501-518.

Błaszkowski J, Niezgoda P, Piątek M, Magurno F et al. 2019a - Rhizoglomus dalpeae, R. maiae, and $R$. silesianum, new species. Mycologia 111(6), 965-980.

Błaszkowski J, Niezgoda P, Paiva JN, Silva KJG et al. 2019b - Sieverdingia gen. nov., S. tortuosa comb. nov., and Diversispora peloponnesiaca sp. nov. in the Diversisporaceae (Glomeromycota). Mycological Progress 18, 1363-1382.

Błaszkowski J, Niezgoda P, Zubek S, Meller E et al. 2021 - Dominikia bonfanteae and Glomus atlanticum, two new species in the Glomeraceae (phylum Glomeromycota) with molecular phylogenies reconstructed from two unlinked loci. Mycological progress 20, 131-138.

Borhidi A, Herrera RA. 1977 - Génesis, características y clasificación de los ecosistemas de sabana de Cuba. Ciencias Biológicas 1(1), 115-130.

Bouza N, Herrera RA, Ferrer RL, Prieto J. 1986 - Perspectivas para la utilización de las micorrizas vesículo arbusculares en el cultivo de los cítricos en Cuba. Ciclo Lectivo sobre el Tema Técnicas de Investigación en Micorriza, CATIE, Turrialba, Costa Rica, 18 al 28 de Sept. de 1985, IFS, Informe Provisional No. 18, 209-234.

Calderón M, González PJ. 2007 - Respuesta del Pasto Guinea (Panicum maximum, cv. Likoni) cultivado en suelo ferralítico rojo lixiviado a la inoculación de hongos micorrízicos arbusculares. Cultivos Tropicales 28 (3), 33-37.

Caravaca F, Alguacil MM, Azcón R, Roldáan A. 2006 - Formation of stable aggregates in rhizosphere soil of Juniperus oxycedrus: effect of AM fungi and organic amendments. Journal of Applied Ecology 33, 30-38.

Chagnon PL, Bainard LD. 2015 - Using molecular biology to study mycorrhizal fungal community ecology: Limits and perspectives. Plant Signaling \& Behavior 10(7): e1046668.

Chaudhary VB, Cuenca G, Johnson NC. 2018 - Tropical-temperate comparison of landscape-scale arbuscular mycorrhizal fungal species distributions. Diversity and Distributions 24, 116-128.

CITMA. 2014 - Ministerio de Ciencia, Tecnología y Medio Ambiente de la República de Cuba. V Informe Nacional al Convenio sobre la Diversidad Biológica. Editorial Academia, La Habana, pp. 253. ISBN 978-959-270-340-7.

Corazon-Guivin MA, Cerna-Mendoza A, Guerrero-Abad JC, Vallejos-Tapullima A et al. 2019 Microkamienskia gen. nov. and Microkamienskia peruviana, a new arbuscular mycorrhizal fungus from Western Amazonia. Nova Hedwigia 109 (3-4), 355-368.

Cruz AJU. 1987 - La vegetación de las arenas blancas de Pinar del Río. Ph.D. diss., Facultad de Biología-Jardín Botánico Nacional, Universidad de La Habana.

Cuenca G, Herrera-Peraza RA. 2008 - Scutellospora striata sp. nov., a newly described glomeromycotan fungus from La Gran Sabana, Venezuela. Mycotaxon105, 79-87.

Cuenca G, Lovera M. 2010 - Seasonal variation and distribution at different soil depths of arbuscular mycorrhizal fungi spores in a tropical sclerophyllous shrubland. Botany 88, 54-64.

de Andrade Z, Furrazola E, Cuenca G. 2017 - Scutellospora tepuiensis sp. nov. from the highland tepuis of Venezuela. Mycotaxon 132, 9-18. 
de la Noval B, Pérez E. 2004 -Inducción de respuestas de defensa en la interacción plantamicroorganismos (micorrizas arbusculares y Rhizobium). Instituto Nacional de Ciencias Agricolas. Ediciones INCA-2004. ISBN 959-7023-21-0.

de la Providencia I. 2002 - Detección de Glomus clarum mediante inmunofluorescencia y ELISA con empleo de anticuerpos monoclonales. [dissertation/master's thesis]. Universidad de la Habana, Facultad de Biología. Ciudad de la Habana.

de la Providencia IE, Fernández F, Pérez E, Rodríguez Y et al. 2002 - Comparación de tres esquemas de inmunización para la obtención de un antisuero policlonal contra Glomus clarum. Cultivos Tropicales 23 (4), 17-22.

de la Providencia IE, de Souza FA, Fernández F, Séjalon-Delmas N, Declerck S. 2004 - Arbuscular mycorrhizal fungi reveal distinct patterns of anastomosis formation and hyphal healing mechanisms between different phylogenic groups. New Phytologist 165(1), 261-271.

de la Providencia IE, Fernández F, Declerck S. 2007 - Hyphal healing mechanism in the arbuscular mycorrhizal fungi Scutellospora reticulata and Glomus clarum differs in response to severe physical stress. FEMS Microbiology Letters 268, 120-125.

de Souza FA, Dalpé Y, Declerck S, de la Providencia I, Séjalon-Delmas N. 2005 - Life History Strategies in Gigasporaceae: insight from monoxenic culture. In: Declerck S, Strullu DG, Fortin JA. Springer-Verlag, Heidelberg (eds). In Vitro Culture of Mycorrhiza, pp.73-91.

Fernández-Suárez K, Declerck S, Fernández-García L, Ortega Delgado E. 2017 - Aplicación del sistema de planta donante de micelio (PDM) en la micorrización in vitro de papa. Cultivos Tropicales 38(1), 31-38.

Ferrer RL, Furrazola E, Herrera RA. 2004 - Selección de hospederos y substratos para la producción de inóculos micorrizógenos. Acta Botánica Cubana 168: 1-10.

Ferrer RL, Herrera RA. 1980 - El género Gigaspora Gerdemann et Trappe (Endogonaceae) en Cuba. Revista del Jardín Botánico Nacional Habana 1, 43-66.

Ferrer RL, Herrera RA. 1985 - Especies micorrízicas cubanas. Revista del Jardín Botánico Nacional Habana 6(1), 75-82.

Ferrer RL, Herrera RA. 1988 - Micotrofia en Sierra del Rosario. In: Herrera RA, Menéndez L, Rodríguez ME, Garcia EE (eds), Ecología de los bosques siempreverdes de la Sierra del Rosario, Cuba. Proyecto MAB No. 1, 1974-1987. ROSTLAC, Montevideo, pp. 473-484.

Ferrer RL, Herrera RA, Cárdenas A, Ruiz M. 1986 - Dependencia micorrízica de Hibiscus elatus Sw. y Cedrela mexicana M.J. Roem cultivadas en condiciones de vivero. Ciclo Lectivo sobre el Tema Técnicas de Investigación en Micorriza, CATIE, Turrialba, Costa Rica, 18 al 28 de Sept. de 1985, IFS, Informe Provisional No. 18, 72-284.

Fitter AH, Helgason T, Hodge A. 2011 - Nutritional exchanges in the arbuscular mycorrhizal symbiosis: implications for sustainable agriculture. Fungal Biology Reviews 25, 68-72.

Franke M, Morton JB. 1994 - Ontogenetic comparisons of arbuscular mycorrhizal fungi Scutellospora heterogama and Scutellospora pellucida: revision of taxonomic character concepts, species descriptions, and phylogenetic hypotheses. Canadian Journal of Botany 72 , $122-134$.

Fundora LR, González J, Ruiz LA, Cabrera JA. 2009 - Incrementos en los rendimientos del cultivo de boniato por la utilización combinada del fitoestimulante Fitomas-E y el biofertilizante Ecomic® en condiciones de producción. Cultivos Tropicales 30(3), 14-17.

Fungi of the Caribbean. 2001 - An annotated checklist. In: Minter DW, Rodríguez-Hernández M, Mena-Portales J. PDMS Publishing, UK, pp. 946.

http://www.cybertruffle.org.uk/cyberliber

Furrazola E, Covacevich F, Torres-Arias Y, Rodríguez-Rodríguez R et al. 2015 - Functionality of arbuscular mycorrhizal fungi in three plant communities in the Managed Floristic Reserve San Ubaldo-Sabanalamar, Cuba. Revista de Biología Tropical 63(2), 341-356.

Furrazola E, Ferrer RL, Orozco-Manso MO, Torres-Arias Y et al. 2011a - Especies de hongos micorrizógenos arbusculares (Glomeromycota) en un agroecosistema de la provincia La 
Habana, con un nuevo reporte para Cuba, Glomus glomerulatum. Acta Botánica Cubana 210, $26-30$.

Furrazola E, Goto BT, da Silva GA, Torres-Arias Y et al. 2013 - Acaulospora herrerae, a new pitted species in the Glomeromycetes from Cuba and Brazil. Nova Hedwigia 97, 401-413.

Furrazola E, Herrera-Peraza RA, Kaonongbua W, Bever JD. 2010 - Glomus candidum, a new species of arbuscular mycorrhizal fungi from North American grassland. Mycotaxon 113, 101-109.

Furrazola E, Torres-Arias Y, Thoen D, Berbara RLL, Jobim K, Goto BT. 2016a - Glomus segmentatum, rediscovery of a rare epigeous sporocarpic fungus to Cuba. Current Research in Environmental \& Applied Mycology 6(2), 143-149.

Furrazola E, Ojeda L, Hernández C. 2016b - Mycorrhizal colonization and species of arbuscular mycorrhizal fungi in grasses from the Cuenca Pecuaria "El Tablón," Cienfuegos, Cuba. Cuban Journal of Agricultural Science 50(2), 321-331.

Furrazola E, Rodríguez-Rodríguez RM, Torres-Arias Y, González-González S et al. 2018 - Hongos micorrizógenos arbusculares (Glomeromycotina) en ecosistemas naturales y agrícolas en la Reserva de la Biosfera Ciénaga de Zapata, Cuba. Acta Botánica Cubana 217 (1), 85-93.

Furrazola E, Sánchez-Rendón JA, Guadarrama P, Pernús M, Torres-Arias Y. 2020b - Mycorrhizal status of Coccothrinax crinita (Arecaceae), an endangered endemic species from western Cuba. Revista Mexicana de Biodiversidad 91: e913048.

Furrazola E, Torres-Arias Y, Ferrer RL, Herrera RA et al. 2011b - Glomus crenatum (Glomeromycetes), a new ornamented species from Cuba. Mycotaxon 116, 143-149.

Furrazola E, Torres-Arias Y, Hernández-Prado R, Gutiérrez Coronill Y. 2019 - Hongos micorrizógenos arbusculares (Glomeromycota) en suelos agrícolas de la provincia Artemisa, Cuba. Acta Botánica Cubana 218(1), 34-43.

Furrazola E, Torres-Arias Y, Herrera-Peraza RA, Fors RO et al. 2020a - Arbuscular mycorrhizal fungi in the rhizosphere of Musa spp. in western Cuba. Current Research in Environmental \& Applied Mycology 10(1), 176-185.

Gemma JN, Koske RE. 1988 - Seasonal variation in spore abundance and dormancy of Gigaspora gigantea and in mycorrhizal inoculum potential of a dune soil. Mycologia 80, 211-216.

Gemma JN, Koske RE, Carreiro M. 1989 - Seasonal dynamics of selected species of V-A mycorrhizal fungi in a sand dune. Mycological Research 92, 317-321.

Gerdemann JW, Trappe JM. 1974 - The Endogonaceae of the Pacific Northwest. Mycologia Memoir5, 1-76.

González-González S, Torres-Arias Y, Ortega-Fors R, Furrazola-Gómez E. 2016 - Hongos micorrizógenos arbusculares (Glomeromycota) de la playa Santa María del Mar, Cuba. Revista del Jardín Botánico Nacional Habana 37, 81-84.

González-Torres LR, Palmarola A, Barrios D. 2013 - Categorización preliminar de taxones de la flora de Cuba. Bissea 7(2), 1-72.

González-Torres LR, Palmarola A, Barrios D, González-Oliva L et al. 2016 - Estado de conservación de la flora de Cuba. En: González Torres LR, Palmarola A, González Oliva L, Bécquer ER, Testé E, Barrios D. (Eds.) Lista roja de la flora de Cuba. Bissea 10 (número especial 1), 1-352.

Goto BT, Jobim K 2021 - Laboratório de Biologia de Micorrizas. http://glomeromycota.wixsite.com/lbmicorrizas (Accessed on August 18, 2020).

Goto BT, Silva GA, Assis DMA, Silva DKA et al. 2012 - Intraornatosporaceae (Gigasporales), a new family with two new genera and two new species. Mycotaxon 119, 117-132.

Halffter G. 1992 - La diversidad biológica de Iberoamérica. CYTED-D, Programa Iberoamericano de Ciencia y Tecnología para el Desarrollo, Acta Zoológica Mexicana.

Herrera RA, Ferrer RL. 1980 - Vesicular-arbuscular mycorrhiza in Cuba. In: Mikola P (ed), Tropical Mycorrhizal Research. Clarendon Press, Oxford, pp. 156-162. 
Herrera RA, Ferrer RL. 1977 - Informe preliminar sobre un método para determinar la densidad de infección en micorrizas vesículo-arbusculares. Ciencias Biológicas 1(1), 147-148.

Herrera RA, Ferrer RL, Prikryl Z. 1984a - Determinación colorimétrica de la densidad de infección en micorrizas VA por extracción del azul de tripán. I Descripción del método. Acta Botánica Cubana 20, ACC, 143-158.

Herrera RA, Ferrer RL, Prikryl Z. 1984b - Determinación colorimétrica de la densidad de infección en micorrizas VA por extracción del azul de tripán. II. Comparación con otros métodos. Acta Botánica Cubana 20, ACC, 159-175.

Herrera RA, Rodríguez A, Furrazola E. 1986a - Método para determinar la biomasa de micelio extramátrico vesículo-arbuscular. Ciclo Lectivo sobre el Tema Técnicas de Investigación en Micorriza, CATIE, Turrialba, Costa Rica, 18 al 28 de Sept. de 1985, IFS, Informe Provisional No. 18, 197-208.

Herrera RA, Rodríguez ME, Orozco MO, Ferrer RL et al. 1986b - Estrategia nutricional de los bosques tropicales: la estera radical y las micorrizas VA. Ciclo Lectivo sobre el Tema Técnicas de Investigación en Micorriza, CATIE, Turrialba, Costa Rica, 18 al 28 de Sept. de 1985, IFS, Informe Provisional No. 18, 167-196.

Herrera RA, Rodríguez ME, Furrazola E. 1988a - Caracterización y dinámica de las fitomasas de raíces y micorrizas vesículo-arbusculares en la Sierra del Rosario. In: Herrera RA, Menéndez L, Rodríguez ME, Garcia EE (eds), Ecología de los bosques siempreverdes de la Sierra del Rosario, Cuba. Proyecto MAB No. 1, 1974-1987. ROSTLAC, Montevideo, pp. 447-472.

Herrera RA, Rodríguez ME, Orozco MO, Furrazola E, Ferrer RL. 1988b - Las micorrizas VA y el funcionamiento de los bosques tropicales. In: Herrera RA, Menéndez L, Rodríguez ME, Garcia EE (eds), Ecología de los bosques siempreverdes de la Sierra del Rosario, Cuba. Proyecto MAB No. 1, 1974-1987. ROSTLAC, Montevideo, pp. 627-670.

Herrera RA, Capote RP, Menéndez L, Rodríguez ME. 1990 - Silvigenesis stages and the role of mycorrhiza in natural regeneration in Sierra del Rosario, Cuba. In: Gómez-Pompa A, Whitmore TC, Hadley M (eds), Rain Forest Regeneration and Management, Man and the Biosphere Series, vol 6. UNESCO and The Parthenon Publishing Group, UK, pp. 201-213.

Herrera RA, Ulloa DR, Valdés-Lafont O, Priego AG, Valdés AR. 1997 - Ecotechnologies for the sustainable management of tropical forest diversity. Nature and Resources 33(1), 2-17.

Herrera RA, Ferrer RL, Sieverding E. 2003 - Glomus brohultii: a new species in the arbuscular mycorrhizal forming Glomerales. Journal of Applied Botany 77, 37-40.

Herrera-Figueroa S, Delgado-Rodríguez G, Iglesias-Brito H, Ortiz-Medina JL et al. 2002 - Hongos de las Reservas de la Biosfera de Cuba I: Listado de las especies reportadas en las Reservas Guanahacabibes y Sierra del Rosario. Revista del Jardín Botánico Nacional 23(2), 223-241.

Herrera-Peraza RA, Cuenca G, Walker C. 2001 - Scutellospora crenulata, a new species of Glomales from La Gran Sabana, Venezuela. Canadian Journal of Botany 79, 674-678.

Herrera-Peraza RA, Furrazola E. 2002 - Influência das taxas de renovação da necromassa no funcionamento exuberante ou austero de micorrizas vesicular-arbusculares (MVA) em floresta tropical. In: Kageyama PY, de Oliveira RE, de Moraes LFD, Bertin-Gandara, F (eds), Restauração Ecológica de Ecossistemas Naturais. Livraria e Editora Agropecuaria, Sao Paulo, Brasil, 167-184.

Herrera-Peraza RA, Furrazola E, Ferrer RL, Fernández R, Torres Y. 2004 - Functional strategies of root hairs and arbuscular mycorrhizae in an evergreen tropical forest, Sierra del Rosario, Cuba. Revista CENIC Ciencias Biológicas 35(2), 113-123.

Herrera-Peraza RA, Hamel C, Fernández F, Ferrer RL, Furrazola E. 2011 - Soil-strain compatibility: the key to effective use of arbuscular mycorrhizal inoculants? Mycorrhiza 21, 183-193. 
Herrera-Peraza RA, Torres-Arias Y, Furrazola E. 2016 - Estructura de las comunidades de hongos micorrizógenos arbusculares en algunos ecosistemas naturales o afectados por la mineria en Moa, Cuba. Acta Botánica Cubana 215(2), 162-195.

Jestrow B, Peguero B, Jiménez F, Verdecia R et al. 2018 - A conservation framework for the critically endangered endemic species of the Caribbean palm Coccothrinax. Fauna \& Flora International 52, 452-463.

Jobim K, Błaszkowski J, Niezgoda P, Kozłowska A et al. 2019 - New sporocarpic taxa in the phylum Glomeromycota: Sclerocarpum amazonicum gen. et sp. nov. in the family Glomeraceae (Glomerales) and Diversispora sporocarpia sp. nov. in the Diversisporaceae (Diversisporales). Mycological Progress18, 369-384.

Khade SW, Rodrigues BF. 2009 - Applications of arbuscular mycorrhizal fungi in agroecosystems. Tropical and Subtropical Agroecosystems 10, 337- 354.

Kowalchuk GA, de Souza FA, van Veen JA. 2002 - Community analysis of arbuscular mycorrhizal fungi associated with Ammophila arenaria in Dutch coastal sand dunes. Molecular Ecology 11, 571-581.

Lee E, Eo JK, Ka KH, Eom AH. 2013 - Diversity of Arbuscular Mycorrhizal Fungi and Their Roles in Ecosystems. Mycobiology 41(3), 121-125.

Ley-Rivas JF, Furrazola E, Collazo E, Medina M. 2009 - Efecto de la aplicación de bentonita sobre la colonización micorrízica y la esporulación de hongos micorrizógenos. Acta Botánica Cubana 206, 34-37.

Ley-Rivas JF, Sánchez JA, Ricardo NE, Collazo E. 2015 - Efecto de cuatro especies de hongos micorrizógenos arbusculares en la producción de frutos de tomate. Agronomía Costarricense 39(1), 47-59.

Ley-Rivas JF, Sánchez JA, Furrazola E, Rodrigez-Rodriguez R, Ricardo OG. 2017 - Variabilidad funcional de hongos arbusculares en el cultivo de papaya en la etapa de vivero. Acta Botánica Cubana 216(1), 47-54.

Martin GM, Rivera R. 2015 - Influence of mycorrhizal inoculation on green manures. Effect on the main crop. A case study: corn. Cultivos Tropicales 36, 3450.

Medina LR, Torres-Arias Y, Herrera RA, Rodríguez Y. 2010 - Aislamiento e identificación de hongos micorrízicos arbusculares nativos de la zona de Las Caobas, Holguín. Cultivos Tropicales 31(4), 33-42.

Montaño NM, Alarcón A, Camargo-Ricalde SL, Hernández-Cuevas LV et al. 2012 - Research on arbuscular mycorrhizae in Mexico: an historical synthesis and prospects. Symbiosis 57, 111126.

Morton JB, Benny GL. 1990 - Revised classification of arbuscular mycorrhizal fungi (Zygomycetes): a new order, Glomales, two new suborders, Glomineaeand Gigasporineae, and two new families, Acaulosporaceae and Gigasporaceae, with an emendation of Glomaceae. Mycotaxon37, 471-491.

Morton JB, Redecker D. 2001 - Two new families of Glomales, Archaeosporaceae and Paraglomaceae, with two new genera Archaeospora and Paraglomus, based on concordant molecular and morphological characters. Mycologia 93, 181-195.

Mujica Y, Batlle J. 2013 - Funcionamiento de la inoculación líquida con hongos micorrízicos arbusculares (HMA) en plantas de tomate (Solanum lycopersicum L.). Cultivos Tropicales 34(4), 5-8.

Mummey DL, Rillig MC. 2007 - Evaluation of LSU rRNA gene PCR primers for analysis of arbuscular mycorrhizal fungal communities via terminal restriction fragment length polymorphism analysis. Journal of Microbiological Methods 70, 200-204.

Oehl F, Laczko E, Bogenrieder A, Stahr K et al. 2010 - Soil type and land use intensity determine the composition of arbuscular mycorrhizal fungal communities. Soil Biology \& Biochemistry 42, 724-738.

Ojeda L, Furrazola E, Hernández C. 2014 - Arbuscular mycorrhizae in legumes of the livestock production enterprise El Tablón, Cuba. Pastos y Forrajes 37(4), 392-398. 
Ojeda L, Furrazola E, Hernández C. 2015 - Response of Leucaena leucocephala cv. Peru to the application of different doses of agricultural MicoFert. Pastos y Forrajes 38(3), 176-182.

Orozco MO, Herrera-Peraza RA, Furrazola E, Torres Y, Martínez MA. 2003 - Patrones de diversidad de hongos endomicorrizógenos asociados a seis leguminosas arbóreas tropicales. Memorias del VII Simposio de Botánica, 23-28 de junio 2003, La Habana. ISBN 959-270029-X.

Orozco MO, Rodríguez M, Herrera RA, Ferrer RL. 1986 - Micorrizas VA, micelio extramátrico y otras poblaciones microbianas asociadas a troncos en descomposición en un bosque tropical. Ciclo Lectivo sobre el Tema Técnicas de Investigación en Micorriza, CATIE, Turrialba, Costa Rica, 18 al 28 de Sept. de 1985, IFS, Informe Provisional No. 18, 251-271.

Peña-Venegas CP, Cardona GI, Arguelles JH, Arcos AL. 2007 - Micorrizas arbusculares del sur de la Amazonia colombiana y su relación con algunos factores fisicoquímicos y biológicos del suelo. Acta Amazónica 37(3), 327-336.

Perotto S, Brewin N, Bonfante P. 1994 - Colonization of pea roots by the mycorrhizal fungus Glomus versiforme and by Rhizobium bacteria: immunological comparison using monoclonal antibodies as probes for plant cell surface components. Molecular Plant-Microbe Interactions 7, 91-98.

Ricardo N, Herrera PP, Cejas F, Bastart JA, Regalado T. 2009 - Tipos y características de las formaciones vegetales de Cuba. Acta Botánica Cubana203, 1-42.

Rillig MC, Mummey DL. 2006 - Mycorrhizas and soil structure. New Phytologist 171, 41-53.

Rinaudo V, Bàrberi P, Giovannetti M, van der Heijden MGA. 2010 - Mycorrhizal fungi suppress aggressive agricultural weeds. Plant and Soil 333, 7-20.

Rivera R, Fernández F, Hernández A, Martin JR, Fernández K. 2003 - El manejo efectivo de la simbiosis micorrízica, una vía hacia la agricultura sostenible. Estudio de caso: El Caribe. INCA, La Havana, pp. 166.

Rivera R, Fernández F, Fernández K, Ruiz L et al. 2007 - Advances in the management of effective arbuscular mycorrhizal symbiosis in tropical ecosystems. In: Hamel C, Plenchette C (eds), Mycorrhizae in crop production: Applying knowledge. Haworth, Binghampton, pp. 151-196.

Rodríguez-Rodríguez RM. 2014 - Micotrofía arbuscular de plantas endémicas de las arenas blancas cuarcíticas de Sabanalamar, Pinar del Río, Cuba. [dissertation/master's thesis]. Instituto de Ecología y Sistemática, La Havana.

Rodríguez-Rodríguez RM, Herrera PP, Furrazola E. 2013 - Arbuscular mycorrhizal colonization in Asteraceae from white sand savannas, in Pinar del Río, Cuba. Biota Neotropica13(3), 136140.

Rodríguez-Rodríguez RM, Torres-Arias Y, Furrazola E. 2014 - Micorrizas arbusculares asociadas a Júcaro de ciénaga (Bucida palustris) y Soplillo (Lysiloma latisiliquum) en la Reserva de la Biosfera Ciénaga de Zapata, Cuba. Revista CENIC Ciencias Biológicas 45(2), 86-93.

Rodríguez Y, Dalpé Y, Séguin S. 2014 - Clasificación taxonómica de la cepa de hongo micorrizógeno arbuscular INCAM-2 como Funneliformis mosseae, syn. Glomus mosseae. Cultivos Tropicales 35 (2), 27-33.

Rodríguez Y, Dalpé Y, Séguin S, Fernández K, Fernández F, Rivera RA. 2011 - Glomus cubense sp. nov., an arbuscular mycorrhizal fungus from Cuba. Mycotaxon 118, 337-347.

Rodríguez-Yon Y, Maistro-Patreze C, Saggin-Junior OJ, Rivera RA et al. 2021 - Development of a taxon-discriminating molecular marker to trace and quantify a mycorrhizal inoculum in roots and soils of agroecosystems. Folia Microbiologica.

Rosendahl S, Stukenbrock EH. 2004 - Community structure of arbuscular mycorrhizal fungi in undisturbed vegetation revealed by analyses of LSU rDNA sequences. Molecular Ecology 13, 3179-3186.

Sánchez C, Rivera R, González C, Cupull R et al. 2000 - Efecto de la inoculación de hongos micorrizógenos sobre la producción de posturas de cafetos en tres tipos de suelos del macizo montañoso Guamuhaya.Cultivos Tropicales 21(3), 5-13. 
Sánchez JA, Furrazola E. 2018 - Ecotecnologías para la restauración ecológica: los tratamientos de semillas y las micorrizas. Editorial Academia, La Habana.

Sanders IR, Ravolanirina F, Gianinnazzi-Pearson V, Gianinnazzi S, Lemoine MC. 1992 - Detection of specific antigens in the vesicular-arbuscular mycorrhizal fungi Gigaspora margarita and Acaulospora laevis using polyclonal antibodies to soluble spore fractions. Mycological Research 96, 477-480.

Schenck NC, Pérez Y. 1990 - Manual for the Identification of VA Mycorrhizal Fungi, $3^{\text {rd }}$. Synergistic Publications, Gainesville.

Sieverding E, Silva GA, Berndt R, Oehl F. 2014 - Rhizoglomus, a new genus of the Glomeraceae. Mycotaxon 129 (2), 373-386

Simon L. 1996 - Phylogeny of the Glomales: deciphering the past to understand the present. New Phytologist 133, 123-134.

Smith SE, Read DJ. 2008 - Mycorrhizal Symbiosis, $3^{\text {rd }}$.Academic Press, New York.

Strullu-Derrien C, Strullu DG. 2007 - Mycorrhization of fossil and living plants. Comptes Rendus Palevol 6-7, 483-494.

Stürmer SL, Kemmelmeier K. 2021 - The Glomeromycota in Neotropics. Frontiers in Microbiology 11, 1-18.

Stürmer SL, Siqueira JO. 2010 - Species richness and spore abundance of arbuscular mycorrhizal fungi across distinct land uses in Western Brazilian Amazon. Mycorrhiza 21, 255-267.

Stutz JC, Morton JB. 1996 - Successive pot cultures reveal high species richness of arbuscular mycorrhizal fungi in arid ecosystems. Canadian Journal of Botany 74, 1883-1889.

Tchabi A, Burger S, Coyne D, Hountondji F et al. 2009 - Promiscuous arbuscular mycorrhizal symbiosis of yam (Dioscorea spp.), a key staple crop in West Africa. Mycorrhiza 19(6), 375392.

Terry E, Ruiz J. 2008 - Evaluación de bioproductos para la producción de tomate (Solanum lycopersicum, Mill) bajo sistema de cultivo protegido. Cultivos Tropicales 29(3), 11-15.

Torres-Arias Y, Furrazola E, Berbara RLL, Jobim K et al. 2017b - Glomus herrerae, a new sporocarpic species of Glomeromycetes from Cuba. Current Research in Environmental \& Applied Mycology 7(3), 155-160.

Torres-Arias Y, Hernández-Prado R, Furrazola Gómez E, Gutiérrez Coronill Y. 2019 - Hongos micorrizógenos arbusculares (Glomeromycota) en el bosque de ciénaga El Embarcadero, en la provincia Mayabeque, Cuba. Acta Botánica Cubana 218(1), 27-33.

Torres-Arias Y, Ortega-Fors R, González-González S, Furrazola E. 2015 - Diversidad de hongos micorrizógenos arbusculares (Glomeromycota) en bosques semicaducifolios de la Ciénaga de Zapata, Cuba. Revista del Jardín Botánico Nacional 36, 195-200.

Torres-Arias Y, Ortega-Fors R, Nobre C, Furrazola-Gómez E, Berbara RLL. 2017a - Production of native arbuscular mycorrhizal fungi inoculum under different environmental conditions. Brazilian Journal of Microbiology 48, 87-94.

Torres R. 2016 - Economic transformations in Cuba: a review. Third World Quarterly 37 (9), 1683-1697.

Turrini A, Giovannetti M. 2012 - Arbuscular mycorrhizal fungi in national parks, nature reserves and protected areas worldwide: a strategic perspective for their in situ conservation. Mycorrhiza 22, 81-97.

Velazco A, Fernández F, Furrazola E, Herrera R. 1993 - Presencia de Acetobacter diazotrophicus en esporas de la familia Endogonaceae. Cultivos Tropicales 14(1), 25-27.

Walker C, Sanders FE. 1986 - Taxonomic concepts in the Endogonaceae: III. The separation of Scutellospora gen. nov. from Gigaspora Gerd. \& Trappe. Mycotaxon 27, 169-182.

Walker C, Harper CJ, Brundrett M, Krigs M. 2021 - The Early Devonian fungus Mycokidstonia sphaerialoides from the Rhynie chert is a member of the Ambisporaceae (Glomeromycota, Archaeosporales), not an ascomycete. Review of Palaeobotany and Palynology 287, 1-11.

Wijayawardene NN, Hyde KD, Al-Ani LKT, Tedersoo L et al. 2020 - Outline of Fungi and funguslike taxa. Mycosphere 11(1), 1060-1456. 
Zhao ZW, Wang GH, Yang L. 2003 - Biodiversity of arbuscular mycorrhizal fungi in a tropical rainforest of Xishuangbanna, southwest China. Fungal Diversity 13, 233-242.

Appendix 1 Arbuscular mycorrhizal fungal classes, orders, families, genera and species recorded in Cuba

\begin{tabular}{|c|}
\hline Class/Order/Family/Genus and Species \\
\hline Archaeosporomycetes \\
\hline Archaeosporales \\
\hline Archaeosporaceae J.B. Morton \& D. Redecker \\
\hline Archaeospora Morton \& D. Redecker \\
\hline Archaeospora myriocarpa (Spain, Sieverd. \& N.C. Schenck) Oehl, G.A. Silva, B.T. Goto \& Sieverd. \\
\hline Archaeospora trappei (R.N. Ames \& Linderman) J.B. Morton \& D. Redecker \\
\hline Intraspora Oehl \& Sieverd. \\
\hline Intraspora schenckii (Sieverd. \& S. Toro) Oehl \& Sieverd. \\
\hline Ambisporaceae C. Walker, Vestberg \& A. Schüssler \\
\hline Ambispora C. Walker, Vestberg \& A. Schüssler \\
\hline Ambispora appendicula Spain, Sieverd. \& Schenck \\
\hline Glomeromycetes \\
\hline Diversisporales \\
\hline Acaulosporaceae J. B. Morton \& Benny \\
\hline Acaulospora Gerdemann \& Trappe \\
\hline Acaulospora denticulata Sieverd. \& Toro \\
\hline Acaulospora elegans Trappe \& Gerd. \\
\hline Acaulospora excavata Ingleby \& C. Walker \\
\hline Acaulospora foveata Trappe \& Janos \\
\hline Acaulospora herreraeFurrazola, B.T. Goto, G.A. Silva, Sieverd. \& Oehl \\
\hline Acaulospora koskei Błaszk. \\
\hline Acaulospora laevis Gerd. \& Trappe \\
\hline Acaulospora longula Spain \& N.C. Schenck \\
\hline Acaulospora mellea Spain \& N.C. Schenck \\
\hline Acaulospora morrowiae Spain \& N.C. Schenck \\
\hline Acaulospora rehmii Sieverd. \& S. Toro \\
\hline Acaulospora scrobiculata Trappe \\
\hline Acaulospora spinosa C. Walker \& Trappe \\
\hline Acaulospora tuberculata Janos \& Trappe \\
\hline Kuklospora Oehl \& Sieverd. \\
\hline Kuklosporakentinensis (Wu \& Liu) Oehl \& Sieverd. \\
\hline Diversisporaceae C. Walker \& A. Schüssler. emend. Oehl, G.A. Silva \& Sieverd. \\
\hline Diversispora C. Walker \& A. Schüssler. emend. G.A. Silva, Oehl \& Sieverd. \\
\hline Diversispora eburnea (L.J. Kenn., J.C. Stutz \& J.B. Morton) C. Walker \& Schüssler \\
\hline Diversispora spurca (C.M. Pfeifer, C. Walker \& Bloss) C. Walker \& Schüssler \\
\hline Diversispora trimurales (Koske \& Halvorson) C. Walker \& A. Schüssler \\
\hline Diversispora varaderana Błaszk., Chwat, Kovács \& Góralska \\
\hline Pacispora Sieverd. \& Oehl \\
\hline Pacispora dominikii (Błasz.) Sieverd. \& Oehl \\
\hline Sieverdingia Błaszk., Niezgoda \& B.T. Goto \\
\hline Sieverdingia tortuosa (N.C. Schenck \& G.S. Sm) Błaszk. Niezgoda \& B.T. Goto \\
\hline Glomerales \\
\hline Entrophosporaceae Oehl \& Sieverd. emend. Oehl, Sieverd., Palez. \& G.A. Silva \\
\hline Claroideoglomus C. Walker \& A. Schüssler. emend. Oehl, G.A. Silva \& Sieverd. \\
\hline Claroideoglomus claroideum (N.C. Schenck \& G.S. Sm.) C. Walker \& A. Schüssler \\
\hline Claroideoglomus etunicatum (W.N. Becker \& Gerd.) C. Walker \& A. Schüssler \\
\hline Claroideoglomus hanlinii Błaszk., Chwat \& Góralska \\
\hline Claroideoglomus lamellosum (Dalpé, Koske \& Tews) C. Walker \& A. Schüssler \\
\hline Claroideoglomus luteum (L.J. Kenn., J.C. Stutz \& J.B. Morton) C. Walker \& A. Schüssler \\
\hline Entrophospora Ames \& Schneid. emend. Oehl \& Sieverd. \\
\hline
\end{tabular}


Appendix 1 Continued.

\begin{tabular}{|c|}
\hline Class/Order/Family/Genus and Species \\
\hline Entrophospora infrequens (I.R. Hall) R.N. Ames \& R.W. Schneid. \\
\hline Viscospora Sieverd., Oehl \& F.A. Souza \\
\hline Viscospora viscosa (T.H. Nicolson) Sieverd., Oehl \& F.A. Souza \\
\hline Glomeraceae Piroz. \& Dalpé. emend. Oehl, G.A. Silva \& Sieverd. \\
\hline Funneliformis C. Walker \& A. Schüssler. emend. Oehl, G.A. Silva \& Sieverd. \\
\hline Funneliformis geosporum (T.H. Nicolson \& Gerd.) C. Walker \& A. Schüssler \\
\hline Funneliformis halonatum (S.L. Rose \& Trappe) Oehl, G.A. Silva \& Sieverd. \\
\hline Funneliformis monosporus (Gerd. \& Trappe) Oehl, G.A. Silva \& Sieverd. \\
\hline Funneliformis mosseae (T.H. Nicolson \& Gerd.) C. Walker \& A. Schüssler \\
\hline Glomus Tul. \& Tul. emend. Oehl, G.A. Silva \& Sieverd. \\
\hline Glomus ambisporum G.S. Sm. \& N.C. Schenck \\
\hline Glomus brohultii Sieverd. \& Herrera \\
\hline Glomus clavisporum (Trappe) R.T. Almeida \& N.C. Schenck \\
\hline Glomus crenatumFurrazola, R.L. Ferrer, Herrera \& B.T. Goto \\
\hline Glomus cubense Y. Rodr. \& Dalpé \\
\hline Glomus herrerae Torres-Arias, Furrazola \& B.T. Goto \\
\hline Glomus glomerulatum Sieverd. \\
\hline Glomus macrocarpum Tul \& C. Tul \\
\hline Glomus magnicaule I.R. Hall \\
\hline Glomus microcarpum Tul. \& C. Tul. \\
\hline Glomus mortonii Bentiv. \& Hetrick \\
\hline Glomus pachycaule (C.G. Wu \& Z.C. Chen) Sieverd. \& Oehl \\
\hline Glomus rubiforme (Gerd. \& Trappe) R.T. Almeida \& N.C. Schenck \\
\hline Glomus segmentatum Trappe, Spooner \& Ivory \\
\hline Halonatospora Błaszk., Niezgoda, B.T. Goto \& Kozłowska \\
\hline Halonatospora pansihalos S.M. Berch \& Koske \\
\hline Oehlia Błaszk., Kozłowska, Niezgoda, B.T. Goto \& Dalpé \\
\hline Oehlia diaphana (J.B. Morton \& C. Walker) Błaszk., Kozłowska \& Dalpé \\
\hline Septoglomus Sieverd., G.A. Silva \& Oehl \\
\hline Septoglomus constrictum (Trappe) Sieverd., G.A. Silva \& Oehl \\
\hline Septoglomus deserticola (Trappe, Bloss \& J.A. Menge) G.A. Silva, Oehl \& Sieverd. \\
\hline Rhizoglomus Sieverd., G.A. Silva \& Oehl \\
\hline Rhizoglomus aggregatum (N.C. Schenck \& G.S. Sm.) Sieverd., G.A. Silva \& Oehl \\
\hline Rhizoglomus clarum (T.H. Nicolson \& N.C. Schenck) Sieverd., G.A. Silva \& Oehl \\
\hline Rhizoglomus fasciculatum (Thaxt.) Sieverd., G.A. Silva \& Oehl \\
\hline Rhizoglomus intraradices (N.C. Schenck \& G.S. Sm.) Sieverd., G.A. Silva \& Oehl \\
\hline Rhizoglomus microaggregatum (Koske, Gemma \& P.D. Olexia) Sieverd., G.A. Silva \& Oehl \\
\hline Sclerocystis Berk. \& Broomee \\
\hline Sclerocystis coremioides Berk. \& Broome \\
\hline Sclerocystis sinuosa Gerd. \& B.K. Bakshi \\
\hline Gigasporales \\
\hline Dentiscutataceae Sieverd., F.A. de Souza \& Oehl \\
\hline Dentiscutata Sieverd., F.A. de Souza \& Oehl \\
\hline Dentiscutata heterogama (T.H. Nicolson \& Gerd.) Sieverd., F.A. Souza \& Oehl \\
\hline Dentiscutata scutata (Walker \& Dieder.) Sieverd., F.A. de Souza \& Oehl \\
\hline Fuscutata Oehl, F.A. de Souza \& Sieverd. \\
\hline Fuscutata heterogama Oehl, F.A. Souza, L.C. Maia \& Sieverd. \\
\hline Fuscutata savannicola (R.A. Herrera \& Ferrer) Oehl, F.A. de Souza \& Sieverd. \\
\hline Gigasporaceae Morton \& Benny. emend. Sieverd., F.A. de Souza \& Oehl \\
\hline Gigaspora Gerdemann \& Trappe. emend. Oehl, F.A. de Souza \& Sieverd. \\
\hline Gigaspora albida N.C. Schenck \& G.S. Sm. \\
\hline Gigaspora decipiens I.R. Hall \& L.K. Abbott \\
\hline Gigaspora margarita W.N. Becker \& I.R. Hall \\
\hline
\end{tabular}


Appendix 1 Continued.

\begin{tabular}{|l|}
\hline Class/Order/Family/Genus and Species \\
\hline Racocetraceae Oehl, Sieverd. \& F.A. Souza \\
\hline Cetraspora Oehl, F.A. de Souza \& Sieverd. \\
\hline Cetraspora gilmorei (Trappe \& Gerd.) Oehl, F.A. de Souza \& Sieverd. \\
\hline Cetraspora pellucida (T.H. Nicolson \& N.C. Schenck) Oehl, F.A. de Souza \& Sieverd. \\
\hline Racocetra Oehl, F.A. de Souza \& Sieverd. \\
\hline Racocetra alborosea (Ferrer \& R.A. Herrera) Oehl, F.A. Souza \& Sieverd. \\
\hline Racocetra fulgida (Koske \& C. Walker) Oehl, F.A. de Souza \& Sieverd. \\
\hline Racocetra minuta (Ferrer \& R.A. Herrera) Oehl, F.A. Souza \& Sieverd. \\
\hline Scutellosporaceae Sieverd., F.A. Souza \& Oehl \\
\hline Scutellospora (Walker \& Sanders) emend. Oehl, F.A. de Souza \& Sieverd. \\
\hline Scutellospora aurigloba (I.R. Hall) C. Walker \& F.E. Sanders \\
\hline Scutellospora calospora (T.H. Nicolson \& Gerd.) C. Walker \& F.E. Sanders \\
\hline Scutellospora tricalypta (R.A. Herrera \& Ferrer) C. Walker \& F.E. Sanders \\
\hline Paraglomeromycetes \\
\hline Paraglomerales \\
\hline Paraglomeraceae J.B. Morton \& Redecker \\
\hline Paraglomus J.B. Morton \& Redecker \\
\hline Paraglomus albidum (C. Walker \& L.H. Rhodes) Oehl, F.A. Souza, G.A. Silva \& Sieverd. \\
\hline Paraglomus occultum (C. Walker) J.B. Morton \& D. Redecker \\
\hline
\end{tabular}

